\title{
Interactive Large Classes: The Dynamics Of Teacher/ Student Interaction
}

Doris A. Christopher (E-mail: dchrist@calstatela.edu), California State University at Los Angeles

\begin{abstract}
The purpose of this paper is to show that there are many techniques and methods to use in stimulating interest and effective learning outcomes in large classes. The paper addresses several alternative teaching formats such as: active learning, collaborative learning, interactive learning which encourage student interaction in the traditional lecture environment. The paper discusses how the web can be used as an instructional tool in large classes to motivate students to find resources, conduct webquests, complete time certain email assignments, and engage in active inclass discussions.
\end{abstract}

\section{Introduction}

$\mathrm{n}$ the Information Systems Department meetings at California State University, Los Angeles, one has to merely mention the word "large lecture" to get a lively, heated debate underway.

Some faculty in the Information Systems Department refer to those instructors who teach those large lecture courses (referred to as "mega sections") of 150+ students as "cash cows." They argue that once faculty agree to teach these large section "work horse" teaching loads that administration will expect this faculty/student ratio on a continual basis. They argue that it is unfair to be expected to teach this many students and maintain the standards established for smaller course sections. How can one give the students enrolled in the large sections and the smaller sections the same quality of instruction. It is impossible, they argue.

The proponents of the large lecture sections argue that large lecture classes generate the numbers, or FTE (full-time equivalent) units, which provide other faculty the opportunity to teach special topic undergraduate and graduate classes that might not otherwise be offered to the student body due to budget and other resource constraints. They argue that the large lecture classes are the "bread-and-butter" of the program. The large sections allow the Department to make the best use of its limited resources while serving the needs of the Department and College. They argue that the large lecture classes generate a fair share of FTE (full-time equivalency) and these mega sections help departments make their projected targets set by the college for the department. Besides, they argue, the same amount of lecture material is covered regardless of class size.

The opponents of the large lecture sections argue that large lecture sections dilute the learning process, place an undue burden on faculty in terms of test monitoring, grading, office hours/student interaction, and course management. They further refer to this kind of teaching as "mob teaching." The opponents argue that large lecture sections are not only unfair to faculty in terms of teaching loads but unfair in terms of offering students a quality education. They argue that administration gets five sections out of a class enrollment of 150 students; whereas the same 150 students would occupy five small class sections. A normal teaching load at CSULA is three sections per quarter and, therefore, they argue that they are essentially teaching the equivalent of two sections each quarter without any further compensation. They further add that faculty cannot engage in any meaningful dialogue/interaction with students because they are too overburdened with massive amounts of homework

Readers with comments or questions are encouraged to contact the author via email. 
assignments, grading, and multiple-test generation/monitoring. To further compound the problem, they argue, the resources are not there to employ a part-time graduate teaching assistant. Some professors argue that they had to hire and pay for graduate teaching assistants with their own funds in order to process the paperwork generated in the large lecture class so they met the course requirements established by the department curriculum/syllabus.

The Information Systems Department teaches two courses-CIS100 and CIS 301--using the large lecture format. CIS 100, Business Computer Systems, a lower division computer system fundamentals course maintains a focus on computer hardware and software concepts. This course is a 4-unit course. All courses at California State University, Los Angeles, are taught on a quarter system. The course involves one hour of large lecture format (150+ students) and three hours of lecture/lab. The lecture/lab sessions are comprised of smaller groups (25 students). When a student registers for the course, they enroll in the large lecture format (a set time frame) and enroll in one of several individual lecture/lab sections. The individual lecture/lab sections are limited to 25 students in each section and are taught by graduate teaching assistants. The lecture/lab classes are limited to 25 students per session due to facility/equipment constraints; the labs are only large enough to contain 25 computer stations. The lecture lab sections are available at various timeframes throughout the week. For example, a student may be enrolled in the large lecture on Monday at 2:30 p.m. and enrolled in a lecture/lab on Tuesday/Thursday from 9:00 - 10:30 a.m. The large lecture component of the course meets once a week with all the students enrolled in the CIS 100 course.

CIS 301, Management Information Systems, an upper division course, maintains a focus on organizational context of computer-based information systems: common business applications, information architecture, and user role in systems development. This course is a 4-unit course. This course is primarily offered solely as a large "mega" course (150+ students). Sporadically, the mega section may run concurrently with a smaller section (35 students) of the same course. Faculty who teach the mega section are given double credit if the enrollment reaches $120+$ students, which means that a faculty may teach 2 courses during that quarter (a mega section course and a regular section course). The normal teaching load for CSU teachers on the quarter system is 3 courses per quarter.

One of the problems often stated by faculty who teach the mega-section CIS 301 course is that "Students do not attend the larger mega class sessions. Students who do attend seem to evaporate as soon as roll is taken." One of the issues raised during department meetings is how to address this problem. What could be done to ensure that live bodies were occupying those seats? What could be done to ensure that the students in the mega sections receive the same quality of education and learning as those students in the smaller class sections?

The mega sections were developed to give the Department more flexibility in course offerings and less budget constraints in managing increasing enrollments with few dollars and fewer resources. The same enrollment surges taking place in the larger mega sections were also occurring with the smaller course sections as well. During a ten-year period the Department saw its graduate classes increase from 15 graduate students per course to well over $45+$ graduate students per course. Even computer lab-oriented courses which were capped at 25 undergraduate students suddenly found themselves serving 35 undergraduate students or more.

However, enrollment increases and budget constraints are likely to result in larger classes. Even if the faculty-student ratio does not increase, increased pressure for faculty to obtain funded research and publish will result in lower class loads and larger numbers per class. Current trends point to more and more large classes. Small classes may be a thing of the past for most of us in the modern university. (McKinnon, 1998)

\section{Literature review}

Over the years, universities have developed various strategies for coping with the need to teach more students despite having insufficient resources to do so in the most effective classroom settings. One professor remarked how he can hardly fathom how his students maintain the stamina and fortitude to sit on the classroom floor due to lack of seats available. "Many of these students are in their last quarter and need the course to graduate." One such strategy that is broadly employed is the use of very large lecture classes for especially introductory survey courses taken by many students. The advantages of these very large lecture sections involve making the expertise of an accomplished faculty member available to many students, while holding down faculty costs and keeping faculty 
teaching loads at a low enough level to permit time for the faculty to continue to develop their expertise and to share learning with a larger audience through research and publication (Webking, 1996).

\section{Defining the Large Lecture: What is a "Large" Class?}

One of the first questions to be addressed is: "What is a large class?" Another question to be addressed is: "Does class size make a difference?

There is no agreed definition of a large class in the literature, nor should there be. Class size is perceived differently dependent upon the person teaching the course. A large class is one that feels large. Signs that the class is 'large' can be: the class is significantly larger than you are used to and the resources can no longer cope with the number of students if you desire individual attention for the students. Large classes are as effective as small classes when the goals involve learning factual information and comprehending that information. When traditional achievement tests are used to measure learning, large classes compare well with smaller classes. Smaller classes have been found more effective when instructional goals involve higher level cognitive skills including application, analysis, and synthesis. Smaller classes are more effective than large ones in affecting student attitudes. In smaller classes students have greater opportunities for interaction with subject matter, with the professor and with one another. If there is one issue that keeps teachers in higher institutions nervous when confronted with large classes, it is how to run practical sessions with the same fervor as they do for small classes (www.dakar.unesco.org/breda_guide/New5.htm).

Large lecture courses have problems. Students typically begin such courses with widely varying skills and knowledge, but the size of the course mitigates against personal attention to specific students needs (Friedlander and Kerns, 1998). Lectures are generally described from the instructor's point of view, and the student's need for interaction with the instructor is not addressed. In fact, lack of interaction is considered one of the major limitations of the traditional lecture (Munson 1992). Furthermore, when students have copies of the lecture notes or a text, a significant percentage would prefer reading them rather than attending classes that offer little or no interaction (Edlich 1993; Sullivan \& McIntosh, 2002).

\section{Large Lecture Challenges: Learning Styles/Teaching Patterns}

According to Twigg (2002):

The lecture method is a push technology. It treats all students as if they were the same- as if they bring to the course the same academic preparation, the same learning styles, the same motivation to learn, the same interest in the subject, and the same ability to learn. The reality is that students with weak skills need more individual attention and more opportunity for interaction, particularly at the beginning of the semester. The large, impersonal lecture format simply cannot accommodate the broad range of student differences. Because the lecture method is largely a one-way technology, it is impossible to employ a variety of sound pedagogical techniques. Most lecture courses are notoriously ineffective in engaging students. The traditional format neither encourages active participation nor offers students an opportunity to learn collaboratively from one another.

The following table developed by Jones (1997) gives an overview of the pattern of teaching and learning for large group instruction. This model reflects the traditional lecture model and does not reflect using the concepts of active learning, problem-based learning, and cooperative/collaborative learning practices. Often when instructors think of large class environments, they perceive an environment where the classroom environment is controlled by one lead facilitator/lecturer with a relatively rigid, inflexible agenda. 
TABLE 1. Patterns of Learning

\begin{tabular}{|c|c|c|c|c|}
\hline $\begin{array}{l}\text { Patterns of } \\
\text { Learning }\end{array}$ & Advantages & Disadvantages & Guidelines & Examples \\
\hline \multirow[t]{5}{*}{$\begin{array}{l}\text { Large } \\
\text { Group } \\
\text { Discussion }\end{array}$} & $\begin{array}{l}\text { Economical use } \\
\text { of time- } \\
\text { Maximum } \\
\text { instructor control }\end{array}$ & $\begin{array}{l}\text { Assumes similarity of attributes } \\
\text { and outcomes }\end{array}$ & $\begin{array}{l}\text { Good organization of } \\
\text { content essential }\end{array}$ & lecture \\
\hline & $\begin{array}{l}\text { Economy of scale } \\
\text { (materials) }\end{array}$ & $\begin{array}{l}\text { Limited interaction } \\
\text { for learner }\end{array}$ & $\begin{array}{l}\text { Best for motivating large } \\
\text { groups }\end{array}$ & $\begin{array}{l}\text { Classroom } \\
\text { presentation }\end{array}$ \\
\hline & $\begin{array}{l}\text { Good for } \\
\text { Presenting the big } \\
\text { picture }\end{array}$ & $\begin{array}{l}\text { Cannot be modified } \\
\text { for individual learners }\end{array}$ & $\begin{array}{l}\text { High in mental activity, } \\
\text { terminology }\end{array}$ & \\
\hline & $\begin{array}{l}\text { Good for when } \\
\text { Everyone needs } \\
\text { the same } \\
\text { information }\end{array}$ & $\begin{array}{l}\text { Learner has no control over } \\
\text { content, pacing, delivery }\end{array}$ & $\begin{array}{l}\text { Notetaking, handouts } \\
\text { important }\end{array}$ & \\
\hline & $\begin{array}{l}\text { Can be supplemented } \\
\text { With small group } \\
\text { interactions }\end{array}$ & & & \\
\hline
\end{tabular}

As shown in Table 1, the use of large group discussion to facilitate a positive teaching/learning environment is dependent on the various patterns of learning which take place in a classroom environment. There are other dynamics occurring in the large classroom environment which impact the teaching/learning process such as: students who feel too intimidated to ask questions in an environment which discourages/limits interaction between faculty and student, and students who lack effective notetaking skills and critical listening skills.

In colleges and universities throughout the country, efforts are underway to transform the classroom from a lecture-based experience to a more active and demanding one for students (Matthews, Cooper, Davidson, \& Hawkes, 1995). According to (Dion, 2001), students often perceive those in charge of large lecture courses to be "possessors of knowledge," the sole provider of information and that students were the "cups to be filled to overflowing." This kind of perception prevents students from seeing the teaching/learning process as a shared effort. However, part of that responsibility rests with faculty who may be reluctant to engage students in a more cooperative endeavor that might empower them to take a more active role in the learning process.

\section{A Shift in the Teaching/Learning Process: An Economy of Scale}

The teaching/learning process is in a state of change and focus is no longer one of teaching/learning input but teaching/learning output. The mode and level of instruction is being revamped in light of faculty workloads, increased enrollments, and content delivery. In the 2001 report presented by the Academic Senate of the California State University, it was stated that:

The CSU suffered seriously from the state's fiscal crisis in the early 1990s. Several key indicators of quality were seriously eroded at that time, and they have not yet returned to the levels of the late 1980s, even though many CSU faculty at that time considered levels then to be barely adequate. Only recently has the CSU's funding per student (in constant dollars) returned to pre-1990 levels. Thus, the CSU faces a potential crisis of greatly increased demand at a time when many indicators of quality - the student-faculty ration, library acquisitions, staff availability, to name only a few-have failed to recover from the earlier crisis of funding.

Lectures are costly--and not just in institutional dollars. We know that many students do not learn from lectures, especially when it comes to retaining skills and knowledge. The passive, one-size-fits-all pegagogy of the lecture is often cited as incompatible with the varied learning needs of individual students. Redesigns that create more active learning environments can lead to real gains in learning (Heterick and Twigg, 1999). 
According to Heterick and Twigg (1999): In the traditional course (at Stanford), the cost of teaching 60 students is $\$ 17,831$ per semester, a per-student cost of $\$ 296.88$. The cost of teaching 180 students is $\$ 26,735$ per semester for a per-student cost of $\$ 148.35$ in the redesigned course. The savings per student $=\$ 148.35$. The savings per semester is $\$ 26,703$ in one section. The savings per semester if adopted in all sections $(+720)=\$ 106,812$.

$$
\text { According to Bourner and Flowers (1997): }
$$

Our students will spend a higher portion of their time being taught with large numbers of other students. The number attending lectures will become larger and seminar groups will become larger. Modular courses will become more common. Lecturers will account for a larger proportion of student class contact time. Work with a tutor in small groups will account for a smaller percentage of class contact time. Individual tuition (the academic tutorial) will become (or has become) a thing of the past. There will be a fall in the likelihood that any individual students will ever get to speak on a one-to-one basis with a member of the teaching staff. Many universities will seek to mitigate this outcome by place more emphasis on personal tutoring systems.

The survival of the basic lecture - a method of teaching by discourse rather than conversation or seminarin this age of technology and electronic media is, in many ways, remarkable. Lecturing is probably the oldest teaching method and remains the most common form of instruction to be found in the United States colleges and universities, despite the fact that some research has shown that lecturing is ineffective, especially if not combined with some alternative style of teaching (www.ku.edu/ cte/resources/teachingtips/lecturing.htm).

Lecture courses are often not as effective as they appear; much of the material that is "covered" by faculty is not learned by students. In fact, research sometimes shows students becoming more confused rather than informed by the lectures, while disguising their lack of real comprehension with "understanding" faces and adequate test scores (Ehrmann, 1995).

\section{Large Lectures: Opportunities and Challenges for Creating an Active Learning Environment}

Lectures, as a rule, have little educational value. People learn by doing, not watching and listening. It is difficult to persuade most students in a large lecture class to open their mouths in front of 120 classmates - it feels too risky for them. One technique is the in-class exercise. Instead of just posing questions to the class as a whole, occasionally assign a task and give the students anywhere from 30 seconds to five minutes to come up with a response (Felder, 1997). According to Hague (1991) the key role of the university lies in interaction; the most important element is interaction with tutors, tutorials, and social activity.

The average student's attention span is between ten and twenty minutes (Penner, 1984). After that, students have difficulty concentrating on the speaker. For each lecture, plan to change the pace every 15 minutes or so to relieve the monotony and recapture students' interest. For example: ask students to solve a problem at their seats or in groups of two or three, give a demonstration, use an audiovisual aid, or tell a story or anecdote (http://teaching.berkeley.edu/bgd/largelecture.html). After 15 minutes students begin to tune out and, although some may continue to take notes, they are no longer processing the information they receive (www.ctl.unc.edu/fyc6.html).

Some active learning formats that work well in a large lecture are cooperative group work (Johnson, Johnson \& Smith, 1991), class-wide discussions (Gullette, 1992), and interactive lectures (Mazur, 1993; Sokoloff, 1994; Van Heuvelen, 1991). The interactive lecture evolves around orderly brainstorming in which students generate ideas in response to a question or prompt (http://teaching.berkeley.edu/bgd/largelecture.html).

One of the potential problems which emerge when undertaking group assignments is the individual who perceives the work as a "free ride" and lets the other group members do all the work. To minimize the likelihood of these situations occurring, the teacher must structure the assignments to assure that the defining conditions of cooperative learning are met: 
- $\quad$ Positive interdependence (if one team member fails to meet his/her responsibilities, everyone loses in some way.

- Individual accountability (each student is held personally accountable fr his/her part and for everyone else's part as well)

- $\quad$ Face-to-face interaction (a least part of the time)

- Development and appropriate use of teamwork skills (leadership, time management, effective communication, and conflict resolution)

- $\quad$ Periodic self-assessment of group functioning (what are we doing well as a group? What do we need to do differently?) (www.dakar.unesco.org/breda_guide/New-5.htm)

Even though some active learning techniques used in small classes may not be suitable for large classes, there are a multitude of active learning exercises that are. Lectures may be interrupted by one-on-one interaction between students. (McKinnon, 1998).

The faculty at Iowa State University have discovered some successful large class teaching methods such as creating working teams in class. Teams of six students are mixed randomly to play off each other's strengths. The students discuss lecture materials in class and learn to be responsible for each other because individual quiz scores reflect the average performance of team members (Dolan, 1996).

In class-wide discussions, they present or defend their own views, and critique the views of other students. In interactive lectures, the instructor not only presents material, but also elicits questions and comments from students, stopping periodically to pose questions for student consideration. These instructional formats allow teachers to probe for students conceptual understanding and allows students to work on tasks that require them to explore their reasoning, not just to give their answers. For these instructive formats to be effective, students and teachers must have the opportunity to formulate their thoughts, questions, and answers in order to ensure a greater depth of discourse. Although cooperative group work gives both students and teachers time to process their thoughts, during class-wide discussions and interactive lectures, instructors should take special care to allow ample time for students to process and reflect on questions and comments (Tobin, 1986; Dufresne, 1999).

Research has shown that large class sizes are not necessarily detrimental to education. It is the quality of the instructor that has the greater effect (Godfrey, 1998).

Some very effective practices to improve the instruction of freshmen and sophomores in traditional lecture and discussion courses are as follows:

- $\quad$ Give students frequent short assignments and quizzes so that you and they will know whether they are understanding the material.

- Intersperse your lectures with questions to students; this makes them active participants in learning.

- $\quad$ Encourage the students to form small study groups; help them get to know one another by giving short team assignments. (http://teaching.berkeley.edu/compendium/suggestions/file212.html).

According to Davis (1993), there are many effective tools and alternatives to lecturing and encouraging student participation:

- $\quad$ Give the entire class an assignment to be carried out before the next class meeting.

- $\quad$ Ask your class to form subgroups of three or four students and pose a specific question or task that the groups can resolve in two or three minutes.

- $\quad$ Ask the class to pair off. Pose a general question that will generate several ideas. Ask each pair to generate as many responses as possible during a designated period (three to four minutes)

- Have students divide into discussion sections (twenty to twenty-five people) that meet in corners of the lecture hall or move into empty neighboring classrooms. Start the whole class off with a common task, and then sit with each group briefly to answer questions, comment on the topic, and get the groups started or back on track. 
The National Institute for Science Education's web FAQ site presented a number of answers to issues teaches of large classes deal with such as the following (www.wcer.wisc.edu/NISE/cl1/cl/question/TQ2-13.htm) :

- Teaching in a large lecture hall: Teaching in a large lecture hall with seats bolted down, facing only one direction is problematic. There is no doubt that teaching in this environment, as compared to a classroom with tables and moveable chairs, places restrictions and makes it generally more difficult to include collaborative learning in the course. It does not, however, prevent the incorporation of small group work and active learning strategies.

- Group vs. individual assignments/skill sets: The group and communication skills students learn by working in teams with a common purpose are skills they can take with them and use throughout their career. When incorporated into a course with care, collaborative learning can be a vehicle for students to learn the material. It can provide a platform for vigorous discussions and debates and a means to develop a framework of knowledge.

- Material coverage: Using collaborative learning in your course will probably reduce the amount of material covered. However ask yourself the following questions: How much material do the students retain using the current method; what type of learning occurs with lectures; how much material do I currently not cover with lectures; what content is really needed for the next course; and how much material can my students cover?

- $\quad$ Student Aversion to Group work: There are many reasons for students dislike of group projects/work. They may feel that certain individuals in the group do not do their assigned portion of the work; they may have had a negative experience in prior group settings, they may realize that collaborative learning places more responsibilities on them whereas a more passive learning approach is just that: passive; they may be comfortable with the lecture-based approach merely because it involves change.

\section{Teaching/Learning Styles: Views and Roles of Student/Teacher Experiences}

Learning styles: There are a variety of student learning styles. Some of these are compatible with lecturebased presentation and others are not. Active learners like to think out loud, to discuss ideas, to experiment with concepts. These students may not be reached with a lecture, but may thrive in a small collaborative group experience.

Traditional views of learning offers learners relatively few roles, most of which are passive: listening, notetaking, following instructions, practicing skills, or performing memory tasks during evaluation (www.wsu.edu/vwsu). Current views of learning and instruction challenge the wisdom of the traditional pedagogic practice by stressing the need for the learner to play an active role in constructing knowledge (Defresne, Gerace, Leonard, Mestre, Wenk, 1999). Effective lectures do not just happen - they are planned. The educator must: establish the purpose of the lecture, consider the logistics of the lecture, plan a variety of approaches (e.g., use of questioning, media, small group activities), and prepare a set of lecture notes (Sullivan, 2002). In-class student activities, buzz groups, and discussions can be even more important in a large class. Students probably will not pay attention the entire class period if you only lecture, so it helps to plan attention breaks (Indiana.edu/ teaching/faqlarge.html)

Although learners must construct their own knowledge, a significant portion of an individual's knowledge is constructed in response to interactions with other human beings. From a social constructivist perspective, most learning is so mediated. Certainly the influence of human interactions on knowledge construction is so pervasive that a proper understanding of learning cannot be achieved without taking into account social dimension. Since much learning is done within a social context, it becomes important to understand how dialogue between a teacher and students, and students, can be used to enhance student learning (Brown, Collins \& Duguid, 1989; Cole, 1985; Hewson, Kerby \& Cook, 1995; Lave, 1988;Vygosky, 1978; Dufresne, Gerace, Leonard, Mestre, \& Wenk, 1999). The idea that students spend some time teaching others is also consistent with the constructivist theory. Teachers understand that explaining something to others is an effective way to help fortify one's own knowledge structure (Green and O'Brien, 2002). 
Getting students to work on assignments in fixed teams relieves the grading problem but introduces another set of problems, most of which have to do with the fact that students in a group may have widely varying levels of ability, work ethics, and senses of responsibility (Felder, 1997). Tasks that are more likely to result in learning are those that are perceived as interesting, doable, and profitable (Pintrich, et al., 1993; Strike \& Posner, 1992). The process of knowledge acquisition is also influenced by classroom contextual factors (Garner, 1990). For example, interactions with teachers and peers can help create an atmosphere with a commitment to understanding. An optimal learning environment, then, should incorporate engagement with teachers and other interested learners (Dufresne, et al. 1999)

\section{Using the Web to Stimulate Large Lectures}

The web has facilitated an exciting way to engage students in active learning. Contrary to the traditional lecture and factual memorization, the World Wide Web as an instructional tool allows student-centered learning where exploration and discussion may inspire students to find information and satisfy their curiosity. Web-based learning can meet individual needs, motivate students to find resources, and to publish with a creative mind. It also promotes cooperation and collaboration amongst faculty and students (Hanson \& Jubeck, 1999).

Web materials: "my intention for constructing a home page for my large lecture section was to reinforce material covered in class, to give the students a chance to engage more extensively with the material, and to give the students more intellectual contact with me." (Desmet, 1997)

\section{Asynchronous vs. Synchronous Learning:}

The traditional asynchronicity, the expectation that students will on their own time work through course material, has allowed, but not fostered multiple orientations or paths to learning. The traditional asynchronicity and the expectation, that students will learn in a setting of their own choice, has allowed limited geographic dispersion of learners due to the ties of the lecture hall. In any classroom there are many different paces, patterns, and paths to learning any subject or skill. Within these individual learners, there are also a limited number of "sub-learnings" that can happen in many different orders (www.wsu.edu/vwsu). Advocates of "community" may demand residencies or synchronous online sessions, sincerely believing that such activities are learner-centered. Others view asynchronous learning environments as a keystone of learner-centeredness because such environments offer students greater flexibility. Is asynchronous communication deriguer if one is learner-centered, or is synchronous exchange an important part of the learning experience? All too frequently, even innovative institutions fall back on a one-sizefits-all approach ("all of our students must do..."), forgetting that students are different and have different needs. What do we really mean by being learner-centered? (Twigg, 2002)

\section{The Relationship Between the Utilization of Active Learning Techniques and Group Collaboration in A Large Class Environment}

Scenario: Course: CIS 301 Management Information Systems (Tuesday 6:10-10:00 p.m.) Enrollment: 175 Class session: A management information systems class session on expert systems. The class begins with a PowerPoint lecture presentation on the concepts of expert system development and design (30 minutes), Lecture 1 referred to as the "mini" lecture is proceeded by a question-and-answer session (10 minutes), the question-andanswer session is then followed by a small group activity (10-20 minutes, time dependent upon activity intensity). To begin the small group activity, the large class is divided into groups of 5 (student-chosen). For this session (10 minutes), the class is asked to respond to a question pertaining to expert systems that the instructor displays on the screen. A few groups are randomly selected by the instructor to share their responses with the entire class (10 minutes).

The instructor then proceeds with "mini" Lecture 2 on expert system models, examples (30 minutes). Mini Lecture 2 is then proceeded by a short film clip pertaining to expert systems in the business environment (20 minutes). A short question-and-answer session follows the film clip (10 minutes). The class is then divided into small groups of 5 (student-chosen) for a group quiz consisting of 10-15 true/false, multiple choice, and fill-in items 
displayed on the screen (20 minutes). The quizzes involve critical thinking and, therefore, the students are encouraged to talk amongst themselves to derive the best group concensus answer, since only one quiz paper is turned in for the entire group. As soon as quizzes are turned in, the correct answers to the quiz items are covered; therefore, giving the students immediate feedback on their responses. The whole process of group quiz interaction is taken quite seriously by the group members. The group members engage in a very active dialogue as to which quiz answer is the correct one.

Immediately following the quiz session is a more intensive activity pertaining to the lecture content. In this session the students are asked to design a very simplistic expert system based on an earlier model presented during mini Lecture 2. This activity will take the students 30 minutes to complete since each step pertaining to forwardchaining and backward-chaining in the expert system design must be recorded on paper to be submitted at the end of class.

Break. As you can see from the above description, over 150 minutes has already been utilized in dynamic, active learning. Students are engaged in the learning process with both the instructor and their peers.

Once class resumes after their mandatory $1 / 2$ hour break for a 4-hour class session, the cycle begins again with mini Lecture 3 and follows the same format - mini lecture, question-and-answer session, group activity and/or quiz. The last 10-15 minutes of the evening session is reserved for wrap-up and an overview of the next session's lecture. At the culmination of the evening's activities, the activity exercises are posted on the course website for the students' review.

Some of the culminating class activities involve a webquest whereby students are instructed to check the website for a time certain activity. The students are instructed to email the activity solution back to the instructor by the time certain deadline which is often within 72 hours. The students are challenged to read the posted webquest activity on the course website and find the solution within a specified timeframe. The students enjoy the challenge and engage in active learning with their classmates by emailing them to collaborate with them on what solution they formulated. This is another method used to make a large class seem more engaging and dynamic.

According to Delaney (1995) email provides an instructor with a very personal means of communicating with students. This is extremely helpful in large classes. An instructor may come to know a student by name via email, and associate the quality of thought and communication, in a way that large lecture class environments cannot.

During the quarter, students are also required to do other out-of-class assignments such as writing a twopage paper every other week on a topic in their assigned end-of-chapter readings. These assignments are holistically graded and points are assigned to each paper. There are two examinations given during the quarter-a mid-term and a final. Each examination consists of 50 test items: true/false and multiple choice. The test items are derived from the class/web lecture notes, reading assignments and class discussions. The examinations are individually administered. No discussion or collaboration is allowed during the examinations.

The class evaluation is broken down into the following areas:

Examinations (2) $\quad 40 \%$

Papers (5) $20 \%$

Webquests (Number of assignments varies) $\quad 10 \%$

Interactive quizzes/projects (varies) $\quad 30 \%$

Is there a lot of work involved with this type of format? YES! However, the dynamics of the exchange occurring in the teaching/learning process is well worth the effort. 
Even in a large lecture format, the Management Information students are involved in developing life-long skills by their participation in large group activities in a number of areas, such as the following skill sets (Zirkle, 2001):

Academic Skills:

- $\quad$ Reading skills: the ability to comprehend printed materials.

- Writing skills: the ability to interpret, apply and transmit information in writing.

- Oral Communication skills: the ability to listen and speak in an effective manner.

Occupational/Technical Skills:

- $\quad$ Basic computer skills: the ability to work in DOS, Windows and/or MacIntosh operating environments

- Advanced Computer skills: familiarity with specific software, e.g., Word Perfect, Excel, PowerPoint, Access, Front Page.

Employability Skills:

- $\quad$ Decision-making skills: the ability to make an effective choice when presented with alternatives

- $\quad$ Problem-solving skills: the ability to identify, analyze, and solve a problem situation

- $\quad$ Creative-thinking skills: the ability to use different modes of thought to generate new ideas

- $\quad$ Teamwork skills: the ability to work cooperatively with a variety of individuals in a job setting.

- $\quad$ Leadership skills: the ability to guide others in the completion of work-related tasks

- $\quad$ Negotiation skills: the ability to work with other individuals to resolve a work-related conflict

- $\quad$ Self-management skills: the ability to set and achieve personal performance goals

Course Management: Challenges and Opportunities

Griffiths (1989) likes the "precept method" of teaching, dividing a large class into small discussion sections with a TA as the preceptor, or leader, for each group. The goals of the precept sections are to integrate the course readings with the lecture material and to sharpen the students' critical thinking and communication skills.

No aspect of the large class is as demanding of instructors' time or as likely to pressure them to adopt impersonal evaluation methods as are the challenges of grading and giving feedback (Lowman, 1987). What are some proper ways to personalize and give feedback in large classes? Gleason (1986) suggests choosing 20 papers each time an exam or assignment is given and adding a few personal comments. In this way, by the end of the semester you will probably have given feedback to a fairly large portion of the class. In classes with large numbers of students, personal contact with each student may well be impossible. But with some effort and a few proven strategies, it is possible to help students feel less anonymous and more valued as individuals (Greenberg \& Carbone, 1996).

Teachers can promote long-term retention of information presented in lectures by using strategies that require a high level of student engagement. Typical fifty-five minute lectures - to say nothing of seventy-five minute or two hour lectures - can surpass students' ability to sustain focused attention. Including mnemonics, such as humor or strategic placement of enthusiasm, is particularly important during the middle of lectures when students may find it difficult to sustain attention. One useful heuristic for the fifty-minute lecture is to lecture for twenty-five minutes; then - in order to energize students and refocus their attention-insert a five-minute demonstration, class exercise, or other mnemonic activity; and then lecture for the final twenty minutes (deWinstanley \& Bjork, 2002).

Another idea might be to try a think-pair-share, where you have a student turn to the person next to them to discuss a problem or question. This will break the flow of the class and help to recapture students' attention. It will also give an opportunity to approach the disruptive students and discuss your concern with them (www.adm.uwaterloo.ca/infotrac/largeclass.htm) 
According to Nelson (1994), we can engage the students collaboratively in this enterprise in several ways. Consider a team-write-discuss-process approach. At the end of each testable unit (maybe eight to twelve minutes in a freshman lecture), we can display a transparency showing a short essay question or a few multiple-choice questions over the unit just taught. The students write down their answers and a brief explanation of why their answer is good and then compare answers. This brief interaction will allow many misunderstandings to be corrected. After these brief collaborations, many students, primed by their small-group discussions, may be more willing to participate in whole-class discussion. Morever, students typically regard it as fair for faculty to call on them to report what their pair concluded, where they often resist being called on in the absence of such interchanges. According to McKeachie (1994), students should be encouraged to write in large classes. One way of doing this is the "one-minute paper." One technique is to announce at the beginning of class that you will interrupt your lecture at some point and give them a topic pertaining to the lecture and that they have one minute (or two or three) to write a paragraph or brief paper on the topic. McGee (1987) recommends asking students to discuss a thought question with the person next to them after the instructor has lectured for fifteen minutes. The students (two-three) would then tell their responses to the whole class. After lecturing for half the class, McGee suggests asking students to write their most important themes mentioned during the lecture. The instructor would then write his/her answers on the overhead and compare their list with the students.

\section{Various Teaching Approaches to Enliven Learning and Enhance Outcomes}

Problem-based Learning: An approach to structuring the curriculum which involves confronting students with problems from practice which provide a stimulus for learning (Boud \& Feletti, 1999). Engel sees problembased learning as a means of developing learning for capability rather than learning for the sake of acquiring knowledge.

Reciprocal Teaching Method: In this method, the skills of comprehension, reasoning, and problem-solving are first modeled by a teacher for the learner. Then the learner performs the skills and receives feedback on his or her performance. Over time, the modeling and feedback fade, and the learner works alone. The student eventually becomes a self-regulated learner who asks and answers questions, identifies comprehension deficits, forecasts predictions, and summarizes the material to be learned (Collins, Brown, and Newman, 1990; Palincsar and Brown, 1984; Rogoff, 1990). Discourse processing plays an important role in helping the learner shift from the shallow waters to the deep, from being a repository of inert knowledge to becoming a vital agent who puts the knowledge into action. (Graesser, Person, \& Hu, 2002).

Self-directed learning: The capacity of adults for critical self-reflection and for changing their lives (Mezirow, 1985). ...that internal force which compels individuals to assimilate, synthesize, and internalize new information, given the circumstances in which they find or expect to find themselves (Fisher, 2001).

Problem-based Learning:

Cooperative learning vs. collaborative learning: These two terms are often used interchangeably. However, according to practioners these two terms are different. Cooperative learning is the methodology of choice for foundational knowledge (traditional knowledge) while collaborative learning is connected to the social constructionist's view that knowledge is a social construct. In cooperative learning the instructor is the center of authority in the class, with group tasks usually more close-ended and often having specific answers. With collaborative learning the instructor abdicates his or her authority and empowers the small groups who are often given more open-ended, complex tasks (Rockwood, 1995; NISE). Cooperative learning means noncompetitive learning, in which the reward structure encourages students to work together to accomplish a common end. Collaborative learning is always cooperative, but takes students one step further: to a point where they must confront the issue of power and authority implicit in any form of learning but usually ignored. Either mode may employ group work; neither depends entirely on this technique. Collaborative learning always takes both the student and the professor "into enemy territory": cooperative learning generally maintains traditional authority structures (Gamson, 1994). 
Another feature of Cooperative learning is face-to-face verbal problem solving, which holds advantages for both skilled and less skilled students. Good students benefit from serving as tutors to the other members of the group; less proficient students receive diagnostic and remedial help from their teammates. Much of this verbal interaction occurs immediately after directed teaching and allows students to elaborate on lecture material and to consolidate this information in long-term memory. Students who are reluctant to participate in large lecture class discussion are often quite comfortable contributing to small group interactions (Cooper \& Mueck, 1990).

Professors might begin using Cooperative Learning simply by pausing after 15 to 20 minutes of lecture and asking pairs of students to reflect on the lecture material in ways suggested by the teacher (Cooper \& Mueck, 1990). Students learn best when they are actively involved in the process. Researchers report that, regardless of the subject matter, students working in small groups tend to learn more of what is taught and retain it longer than when the same content is presented in other instructional formats. Students who work in a collaborative group also appear more satisfied with their classes (Beckman, 1990; Chickering and Gamson, 1991; Collier, 1980; Cooper and Associates, 1990; Goodsell, Maher, Tinto, and Associates, 1992; Johnson and Johnson, 1989; Johnson, Johnson, and Smith, 1991; Kohn, 1986; McKeachie, Pintrich, Lin, and Smith, 1986; Slavin, 1980, 1983; Whitman, 1988). The problems of the very large group are mainly those of anonymity and hence passivity and hence attention drift. Deal with drifting attention by a lively lecturing style, and by breaking up the one-hour lecture into 10-15 minute chunks (Atherton, 2001).

Active Learning: Create small ad hoc groups (or pairs) that work in class on a focused question, problem, or exercise; this gives students an opportunity to interact and really engage the material, and it also gives them a needed lecture break. Those with recitation sections sometimes assign the group problems there, and then hear reports in the lecture. Another variation is to have group members role play various positions as they debate a given claim or issue (www.psu.edu/celt/largeclass/lcfaq.shtml)

\section{The Instititution, Teacher, and Student: Adding Value to the Educational Process}

The Institution: Some institutions, especially inflexible institutions of higher learning need to provide the environment necessary to allow self-directed learning to take place (Marsick, 1985).

The Student: Adults bring to a learning situation many varied lifetime experiences with which to filter and interpret new information whether it is in a formal computer science classroom, experimenting with a new recipe, or rebuilding a carburetor. Adults feel they need to know only what is useful to them and will learn it when they feel it is important (Knowles, 1990). It is "right now" learning. They want to see and be able to use the benefits of the learning experience immediately as opposed to learning something for future use as is the case with much of secondary education. The future for them is now (Fisher, 2001).

The Teacher: Some instructors may need to adjust, reorient, and in some cases, redesign the way they instruct in order to meet ethical considerations of integrity in truly meeting adult learners' needs (Fisher, 2001).

The Teacher: "For years I have taught a large general education course. My approach has been traditional (standard text, lecture, multiple-choice tests). Students acquire a lot of new information in my course, but I am concerned that their understanding of themselves and how they affect and fit into the natural world is not significantly deepened. I propose to radically this course so it gives students..." (Christopher Uhl, Biology, College of Science, University Park;CETL-psu.edu/celt).

"Innovative, interactive teaching and learning technologies can benefit large classes as the students have access to course materials via the Internet (searchable FAQ databases, interactive quizzes, fast track communication tools)" (Sehoya Harris, Mitchell D. Price, Sharon P. Shriver, Biology, College of Science, University Park; CETLpsu.edu/celt).

"Aside from trying to use video, poetry, and literature and music whenever appropriate, I never lecture for longer than a few minutes at a time, before throwing out questions to the students. I never under any circumstances 
read my notes. I glance at them, but I am always watching the students-actually looking into their eyes-to monitor their responses, when I see glazed eyes, closed eyes, irritation, annoyance, etc., I try to change tacks, shift gears, and improvise something better.” (Kelsky, 1997)

Aronson (1987) notes that the best way to keep students in large classes interested in classroom material is to present lectures that are stimulating and exciting and, if possible, have an element of humor. Be as conversational as you can. Your position alone, standing before a large room, establishes a certain distance. Students are not there for a formal speech. They need information, organized coherently and presented comprehensibly, and the opportunity to interact with someone who knows and loves the material. So, relax, act naturally, and talk with those people (Magnan, 1990).

When it comes to selecting climates conducive to learning, most faculty members would probably not choose large courses. There are certain aspects of those environments that make them less than ideal for quality instruction. In the case of faculty-student interaction, this is certainly true. Large courses inhibit communication (Gleason, 1999).

Goldhaber (2001) states that one should avoid at all costs standing in front of the room and reading notes or slides or just talking from a distance to students who are often bored, sleeping, or hiding. He uses the Phil Donohue approach technique in his lectures in which he effectively engages student as he dashes around the room, using a wireless mike, to keep students alert and expectant as to who will be called on next to respond. He gives out prizes for participation in exercises and top test scores as a motivation. Students love this (http://wings.buffalo.edu/vpaa/ctlr/files/teaching_strategies/phil_donohue.htm).

Be willing to take a limited number of questions from the class. You can't take too many because it will completely disrupt the flow of your lecture and you will lose the majority of the room. Be sure to repeat the question so everyone knows what it is that you are answering. Do not refuse to take questions - it just reinforces the opinion many of the students have already formed that faculty members are unapproachable and arrogant (Johnson, 2002).

A common problem which occurs when questioning students is the lack of time provided to them in order that they may collect their thoughts and respond. The instructor should provide a wait time of at least 10-20 seconds depending on the type of question posed. When students do respond, the instructor must be interested in the student and his or her response. It would be appropriate for the instructor to develop active listening skills to facilitate the process (Seeler, Turnwald, and Bull, 1994).

\section{The Team Approach to Collaborative Learning}

Team Structure: In organizing groups, teachers typically do four things:

- $\quad$ They divide a large group - the class - into small groups

- $\quad$ They provide a task, usually designed (and, preferably, tested) ahead of time, for the small groups to work on

- $\quad$ They reconvene the larger group into plenary sessions to hear reports from the small groups and negotiate agreement among the group as a whole.

- $\quad$ They evaluate the quality of student work, first as referee, then as judge.

- (Brufee, 1993)

Group Development: Groups take time to development. Many factors impact the group dynamics such as size, frequency of interaction, structural features, etc. The forming stage of the group is often characterized by shyness, uncertainty, and diffidence among the members. Although the extrovert members may rapidly assume leadership. In the storming stage, there is a period of jockeying for position, authority, and influence among the members. This is a testing time and the initial leaders may not survive this period. 
McKeachie (1986) uses a buzz group technique to insure student participation in large classes. In his lectures, when he comes to a concept that lends itself to discussion, he asks students to form groups of from five to eight people to talk about the issue. He instructs them to make sure each member of the group contributes at least one idea to the discussion. After ten minutes, he calls on some of the groups to report and asks other groups who came to the same conclusion to raise their hands. As they report, he records their main points on the blackboard and then incorporates the material into the lecture.

Dill (1977) describes a technique called ke ts'ao, or ferment, used in China to get large groups to come to a concensus decision. Small groups discuss an issue for a time and report their conclusions to the whole assembly. After every group is heard from, they are given additional information if necessary, and return to small-group deliberations. The process is repeated until they achieve a concensus on the problem (ctl.unc.edu/fyc2.html).

Class/Group Culture: In teaching the initial constitution of a course is formal. It is the task- the aims and objectives of the course - which dominates. But as class groups develop, they acquire informal features, which may come to dominate. The teacher, of course, represents the formal system, and the issue of how much he/she can or ought to get involved informally is debatable; it could undermine his/her formal role or perhaps enhance it (Atherton, 2001). One thing about group interaction is to form a more flexible structure in the groups. It is important to change a group member or members within a group to promote interaction within the class as a whole. One way of doing this is to assign individuals a number (i.e. 1-5) and place all the ones together, the twos and so on.

Group work is often conducted in ways which students see as unfair: dividing groups so that members of the same ethnic group are not allowed to work together; giving grades for the group product with no acknowledgement of individual effort; having no method of monitoring members who do not contribute to the group effort; requiring groups to work together outside of class which can impose special hardships on commuters or students with childcare considerations. Successful teaching involves more than improving lecture methods, employing new technologies and involving students in the learning process. Effective teaching includes an understanding of students and their perceptions of fair practices in the classroom (Rodabaugh, 1995; ucsb.edu/IC/Resources/LargeClasses.html)

\section{Conclusions}

The major purpose of this paper was to show how interactive learning can be integrated into the large classroom without losing the focus of the lecture material. The innovative use of technology can provide a seamless interface in the large classroom with webquest assignments which the students find stimulating and challenging. The methods such as active learning, collaborative learning, cooperative learning, problem-based learning--mentioned in the paper make large classes more engaging and interesting for both student and teacher. The interactive process allows students to reflect on their learning experiences, facilitating a higher order of learning. The interactive process promotes good communication abilities and effective interpersonal skills, while introducing and/or enhancing their technology skills, time management skills, and research skills.

The interactive large lecture format requires more time on the part of the instructor since each lecture is broken into various activities, exercises, quizzes, and feedback sessions. However, the rewards far outweigh the work of creating a "roadmap" of teaching/learning sessions. The students attend class, they are more accountable to their course of study, their peers, and their assignments. The personal contact with their team members and the sense of commitment they display are worth the planning efforts of designing such an interactive course.

\section{References}

1. Add Active Learning to Large Classes: http://instruct1.cit.cornell.edu/courses/taresources/large.html

2. Asynchronous Learning: http://www.wsu.edu/vwsu/RFP9631/WP1101496.html

3. Beckman, Mary. "Collaborative Learning: Preparation for the Workplace and Democracy." College Teaching. Fall 1990, 38(4), 128-133. 
4. $\quad$ Berger, Jim. "Experimenting with the Web-based Material to Support a Large Lecture Course." http://www.cstudies.ubc.ca/facdev/services/registry/ewwbmtsallc.html

5. Berkeley Compendium: "Implement Good Practices in Teaching Large Lecture Courses." Suggestions for Teaching with Excellence. Issue 212: http://teaching.berkeley.edu/compendium/suggestions/file212.html

6. Boud, David and Grahame Feletti. The Challenge of Problem-Based Learning $2^{\text {nd }}$ Edition. London: Kogan Page, 1997. 15-16.

7. Bourner, Tom and Steve Flowers. "Teaching Learning Methods in Higher Education: A Glimpse of the Future". A Journal of the Higher Education Foundation (1997): Vol. 9, 77-102.

8. Bouton, C. and R. Garth. New Directions for Teaching and Learning: Learning in Groups. No.14. San Francisco: Jossey-Bass 1983.

9. Bruffee, Kenneth A. Collaborative Learning: Higher Education, Interdependence, and the Authority of Knowledge. Baltimore and London: The Johns Hopkins University Press, 1995, 28-51.

10. Butler, Darrell L. "Using a Web Site in a Large Lecture Class to Help Student with Personal Learning Projects.” The Technology Source. Jul/Aug. 2001: http://ts.mivu.org/default.asp?show+article\&id+864

11. Carbone, Elisa. "Using Storytelling to Make Lectures Lively and Vivid." The Large Classes Newsletter. Issue 1 Jan.1996: http://www.cte.umd.edu/library/lcn/lcn1.html

12. Carbone, Elisa. "Using Demonstrations and Dramatic Devices in Large Classes." The Large Classes Newsletter. Issue 2 Feb.1996: http://www.cte.umd.edu/library/len/len2.html

13. Carbone, Elisa. "Personalizing the Large Class." The Large Classes Newsletter. Issue 5 May.1996: http://www.cte.umd.edu/library/lcn/lcn5.html

14. Center for Teaching and Learning. "Classroom Activities for Active Learning." For Your Consideration. Issue 2. Oct. 1988: http://ctl.unc.edu/fyc2.html

15. Center for Teaching and Learning. "Ideas for Teaching Large Lecture Classes."

16. For Your Consideration. Issue 5. Oct. 1989: http://ctl.unc.edu/fyc5.html

17. Center for Teaching and Learning. "Thoughts on the Lecture Method." For Your Consideration. Issue 6. Nov. 1989: http://ctl.unc.edu/fyc6.html

18. Center for Teaching Excellence. "Teaching Roles: Lecturing.": http://www.ku.edu/resources/teachingtips/lecturing.html

19. Center for Excellence in Learning and Teaching. "Funded FELT Projects: Improving Large Class Sections.": http://www.psu.edu/celt/grants/FELT12.html

20. Chickering, A. W., and Gamson Z. F. "Applying the Seven Principles for Good Practice in Undergraduate Education." New Direction for Teaching and Learning. No. 47. San Francisco: Jossey-Bass, 1991.

21. Collier, K.G. "Peer-Group Learning in Higher Education: The Development of Higher-Order Skills." Studies in Higher Education. 1980 5(1), 55-62.

22. Cooper, J. and Associates. "Cooperative Learning and College Instruction.” Long Beach: Institute for Teaching and Learning, California State University, 1990.

23. Cooper, Jim and Mueck, Randall. "Student Involvement in Learning: Cooperative Learning and College Instruction.” Journal on Excellence in College Teaching. No.1, 1990: 68-76.

24. Davis, Barbara Gross. Tools for Teaching. San Francisco: Jossey-Bass, 1993, 131-139.

25. Davis, Barbara Gross. Tools for Teaching. Preparing to Teach the Large Lecture Course: http://teaching.berkeley.edu/bgd/largelecture.html

26. Delaney, Edward J. and Krumme, Gunter. "What have we Learned From Our Electronic Mail Experience in the Classroom. E-mail in Classes." : http://faculty.Washington.edu/ krumme/projects/jghevers.html

27. "Delivering Effective Lectures." JHPIEGO Strategy Paper. December 1996: http://www.reproline.jhu.edu/english/6read/6training/lecture/delivering_lecture.htm

28. Dr. Desmet. English 231. Computer Questionnaire: http://virtual.park.uga.edu/cdesmet/websurv.htm

29. Dr. Desmet. English 231. Results of Computer Questionnaire: http://virtual.park.uga.edu/cdesmet/webinfo.htm

30. Dr. Desmet. English 231. Teaching With the Web: http://virtual.park.uga.edu/cdesmet/231study.htm

31. Dr. Desmet. English 231. Discussions of Dr. Desmet's English 231 Home Page: http://virtual.park.uga.edu/cdesmet/discuss.htm

32. Dr. Desmet. English 231. Conclusions from Computer Questionnaire: http://virtual.park.uga.edu/cdesmet/webcon.htm 
33. deWinstanley, Patricia Ann and Bjork, Robert A. "Successful Lecturing: Presenting information in Ways That Engage Effective Processing." New Direction for Teaching and Learning. No. 89, Spring 2002: 19-31

34. Dion, Linda. "But I Teach a Large Class." Newsletter of the Center for Teaching Effectiveness. Spring 1996: http://www.udel.edu/pbl/cte/spr96-bisc2.html

35. Dolan, Ann. "Instructors Share Ideas: Large Class Teaching Tips.” Teaching Tips: http://www.cte.iastate.edu/tips/large.html

36. Dufresne, Robert J., Gerace, William J., Leonard, William J., Mestre, Jose P., and Wenk, Laura. "Classtalk: A Classroom Communication System for Active Learning." Journal of Computing in Higher Education.

37. No. 7: 3-47: http://umperg.physics.umass.edu/projects/ASKIT/ClasstalkPaper

38. Ehrlich, Robert. “The Deans' Discussion Forum: Enhancing Learning in Large Classes.” Inventio. Oct. 1999, Issue 2, Vol.1: http://www.doiiit.gmu.edu/Archives/Oct99/rehrlich_1.htm

39. Ehrmann, Stephen C. "Restructuring Large Introductory Courses: Using Technology to Transform the Foundation of Higher Education.” Annenberg/CPB Learner.org: http://www.learner.org/edtech/techstrats/restruct.html

40. Fisher, Thomas D. "Self-Directedness in Adult Vocational Education Students: Its Role in Learning and Implication for Instruction." Journal of Vocational and Technical Education. Vol.11, No. 2:

41. http://www.scholar.lib.vt.edu/ejournals/JVTE/v11n2/fisher.html

42. "Patterns of Teaching and Learning." Focus on the Student: Designing Library Instruction for Critical Thinkers.: http://www.cabrillo.cc.caus/thinking/patterns.html

43. Friedlander, Larry and Kerns, Charles. "Transforming the Large Lecture Course.": http://sll.stanford.edu/pubs/friedkerns.html

44. Gleason, Maryellen. "Better Communication in Large Courses." Center for Teaching and Learning:

45. http://www.wmich.edu/teachlearn/winter2000/teaching/lgclass.htm

46. Godfrey, Keith. "Tips for Lecturing Large Classes of First year Students.” Teaching and Learning: http://cea.curtin.edu.au/tlf/tlf1998/godfrey.html

47. Goldhaber, Gerald M. "The Phil Donohue Approach to Large Lecture Halls.” University at Buffalo: Center for Teaching and Learning Resources:

48. http://wings.buffalo.edu/vpaa/ctlr/files/teaching_strategies/phil_donohue.htm

49. Goodsell, A., Maher, M., Tinto,V. , and Associates. Collaborative Learning: A Sourcebook for Higher Education. University Park: National Center on Postsecondary Teaching, Learning, and Assessment, Pennsylvania State University, 1992.

50. Graesser, Arthur C., Person, Natalie K. and Hu, Xiangen. "Improving Comprehension Through Discourse Processing." New Direction for Teaching and Learning. No. 89, Spring 2002: 33-44

51. Greenberg, James and Carbone, Elisa (Editors). "Electronic Communication for Large Classes." The Large Classes Newsletter. Issue 3 Mar 1996: http://www.inform.umd.edu/EdRes/FacRes/CTE/lcn/lcn3.html

52. Green, Douglas and O'Brien, Thomas. "The Internet's Impact on Teacher Practice and Classroom Culture." The Journal. Jun 2002: 42-51

53. Hanson, R. H. and Jubeck, Todd. "Assessing the Effectiveness of Web Page Support in a Large Lecture Course.”: http://www.ctu.du.vn/ vdquynh/dedu/deosn9_9.htm

54. Hensley, Thomas R. and Maureen Oakley. "The Challenge of the Large Lecture Class: Making it More like a Small Seminar.” PS Online: Political Science and Politics. Find Articles: http://www.aspanet.org/PS/march98/hensley.cfm

55. Heterick, Bob and Twigg, Carol. "Lectures Are Not Cheap.” Tomorrow's Professor. Message \# 160: http://learninglab.stanford.edu/projects/tomprof/newtomprof/postings/160.html

56. Ideas for Effective Teaching of Large Classes: http://www.duq.edu/Publications/CTE/art3.html

57. Johnson, Dana. "Teaching in Large Classes.": http://tep.uoregon.edu/resources/librarylinks/articles/largeclass.html

58. Johnson, D.W., and Johnson R.T. Cooperation and Competition: Theory and Research. Edina, Minn.: Interaction Books, 1989.

59. Johnson, D.W., Johnson R.T., and Smith K.A. "Cooperative Learning: Increase College Faculty Instructional Productivity." ASHE-ERIC Higher Education Report. No.4. Washington, D.C. School of Education and Human Development, George Washington University, 1991. 
60. Kadel, Stephanie and Keehner, Julia A. Collaborative Learning: A source for Higher Education. Vol II. National Center on Postsecondary Teaching, Learning and Assessment, 1994, 65-79.

61. Kelsky, Karen. "Clicking with Large Classes." Lizard. No. 43, Fall 97: http://tep.uoregon.edu/workshops/teachingsupport/largeclasses/clicking.html

62. Kohn, A. No Contest: The Case Against Competition. Boston: Houghton Mifflin, 1986.

63. Kurian, Lizyamma, Hulina, Paul T., Coraor, Lee D., and Mannai, Dhamir N. "Classification and Performance Evaluation of Instruction Buffering Techniques.” 1991:

64. http://citeseer.nj.nec.com/kurian91classification.html

65. Magnan, Robert. 147 Practical Tips for Teaching Professors. Madison, Wisconsin: Atwood Publishing, 1990.

66. Matthews, Roberta S, Cooper, James L., Davidson, Neil, and Hawkes, Peters. "Building Bridges Between Cooperative And Collaborative Learning." Change. July/August 1995: 35-42

67. McGee, Reece: http://id-www.ucsb.edu/IC/Resources/LargeClasses.html

68. McKeachie, W.J. Teaching Tips: Strategies, Research and Theory for College and University Teacher. $\left(9^{\text {th }}\right.$ Edition) Lexington, MA: D.C. Heath and Company 1994.

69. McKeachie, W.J. Teaching Tips: Strategies, Research and Theory for College and University Teacher. $\left(8^{\text {th }}\right.$ Edition) Lexington, MA: D.C. Heath and Company 1986.

70. McKeachie, W.J., Pintrich, P.R., Lin, Y.-G., and Smith, D. A. F. "Teaching and Learning in the College Classroom: A Review of the Research Literature.” Ann Arbor: National Center for Research to Improve Postsecondary Teaching and Learning, University if Michigan, 1986.

71. McKinney, Kathleen. "Ideas for Incorporating Writing into Large Courses.": http://parallel.park.uga.edu/ mballif/ideas2.html

72. McKinney, Kathleen. "Writing in Large Classes: Don’t Be Overwhelmed With Grading!” Center for Advancement in Teaching:

73. http://www.cat.ilstu.edu/teaching_tips/handouts/massgrading.shtml

74. McKinnon, Tom. "I Would Like To But...I Teach a Large Class." TFSC Newsletter. Apr 1998: http://www.uark.edu/misc/tfscinfo/news498.html

75. Minnesota Model for Large Introductory Courses:

76. http://groups.physics.umn.edu/physed/Research/MNModel/MNt.html

77. Module 5: Effective Teaching and Learning in Large Classes.

78. http://breda-guide.tripod.com/New-58.htm

79. Nelson, Craig E. "Critical Thinking and Collaborative Learning." New Directions in Teaching and Learning. Fall 1994: 45-58.

80. Ramage, John D. and Bean, John C. "Teaching Writing in Large Classes: Seven Years Later at Montana State University." ADE Bulletin. 097, Winter 1990:18-25:

http://www.ade.org/ade/bulletin/n097/097018.htm

81. Resources for Teaching Large Classes:

82. http://id-www.ucsb.edu/IC/Resources/LargeClasses.html

83. Rockwood, H. S.III (1995a). "Cooperative and Collaborative learning." The National Teaching and Learning Forum. 4 (6), 8-9.

84. Rockwood, H. S.III (1995b). "Cooperative and Collaborative learning." The National Teaching and Learning Forum. 5 (1), 8-10.

85. Rodabaugh, Rita and Svinicki, M (Editior). "In the Name of the Students." Teaching Excellence: Toward the Best in the Academy. Professional and Organizational Development Network in Higher Education. 6, (3). 1994-1995.

86. Rojewski, Jay W. "Effects of Economic Disadvantaged Status and Secondary Vocational Education on Adolescent Work Experience and Postsecondary Aspirations. ” Journal of Vocational and Technical Education. Vol.14, No. 1: http://scholar.lib.vt.edu/ejournals/JVTE/v14n1/JVTE-4.html

87. Seeler, D.C., Turnwald, G.H. and Bull, K.S. "From Teaching to Learning: Part III. Lectures and Approaches to Active Learning." Journal of Veterinary Medical Education.: http://scholar.lib.vt.edu/ejournals/JVME/V21-1/Seeler1.html

88. Silberman, Mel. Active Learning 101 Strategies to Teach Any Subject. Boston, London, Toronto, Sydney, Tokyo, and Singapore: Allyn and Bacon, 1996. 
89. $\quad$ Slavin, R.E. “Cooperative Learning.” Review of Educational Research. 1980, 50(2), 315-342.

90. Slavin, R.E. "When Does Cooperative Learning Increase Student Achievement?" Psychological Bulletin. 1983, 94(3), 429-445.

91. "Frequently Asked about Teaching Large Classes." Teaching Resources Center: http://www.iub.edu/ teaching/faqlarge.html

92. "The Change-ups in Lectures." Teaching Resource Center: http://www.iub.edu/ teaching/changeups.html

93. "Large Classes: Limiting the Chaos." Teaching Resources and Continuing Education (TRACE). TRACE Tip Sheet: http://www.adm.uwaterloo.ca/infotrak/largeclass.html

94. “Topics for Teachers. Teaching Large Classes.”: http://cstl.syr.edu/cstl/T-L/Lg_cls.htm

95. Tough Questions: "I can't cover all the material" http://www.wcer.wisc.edu/nise/CL1/CL/question/TQ2.htm

96. Tough Questions: "My students need to work independently" http://www.wcer.wisc.edu/nise/CL1/CL/question/TQ4.htm

97. Tough Questions: "The real world is competitive" http://www.wcer.wisc.edu/nise/CL1/CL/question/TQ5.htm

98. Tough Questions: "My students don't like or want to work in groups" http://www.wcer.wisc.edu/nise/CL1/CL/question/TQ8.htm

99. Tough Questions: "I teach in a large lecture hall." http://www.wcer.wisc.edu/nise/CL1/CL/question/TQ9.htm

100. Tough Questions: "I learned with lectures. Why can't my students?" http://www.wcer.wisc.edu/nise/CL1/CL/question/TQ10.htm

101. Tough Questions: "Collaborative versus cooperative learning?" http://www.wcer.wisc.edu/nise/CL1/CL/question/TQ13.htm

102. Twigg, Carol A. "Improving Learning \& Reducing Costs: Resigning Large-Enrollment Courses." The Pew Learning and Technology Program: http://center.rpi.edu/PewSym/mono1.html

103. Twigg, Carol A. "Who Owns Online Courses and Course Material? Intellectual Property Policies for a New Learning." The Pew Learning and Technology Program: http://center.rpi.edu/PewSym/mono2.html

104. Twigg, Carol A. "Quality Assurance for Whom? Providers and Consumers in Today's Distributed Learning Environment." The Pew Learning and Technology Program: http://center.rpi.edu/PewSym/mono3.html

105. Twigg, Carol A. "Innovations in Online Learning: Moving Beyond No Significant Difference." The Pew Learning and Technology Program: http://center.rpi.edu/PewSym/mono4.html

106. “Group Cultures.” Using the Class Group.: http://www.dmu.ac.uk/ jamesa/teaching/group_cultures.htm

107. “Group Development.” Using the Class Group.: http://www.dmu.ac.uk/ jamesa/teaching/group_ development.htm

108. “Group Size.” Using the Class Group.: http://www.dmu.ac.uk/ jamesa/teaching/group_size.htm

109. "Small Working Groups." Using the Class Group.: http://www.dmu.ac.uk/ jamesa/teaching/small_group_working.htm

110. "Working with Large Groups.” Using the Class Group.: http://www.dmu.ac.uk/ jamesa/teaching/groups_large.htm

111. Webking, Robert. "The Effective use of Multimedia in Large Classes." Effective use of Multimedia Resources.: http://www.utep.edu/politics/analysis.htm

112. Whitman, N.A. "Peer Teaching: To Teach Is to Learn Twice." Washington D.C. ASHE-ERIC Higher Education Report. No.4. Washington, D.C.: Association for the Study of Higher Education, 1988.

113. Zirkle, Chris. "Perceptions of Vocational Educators and Human Resource/Training and Development Professionals Regarding Skill Dimensions of School-to-Work Transition Programs. "Journal of Vocational and Technical Education. Vol.15, No. 1: http://scholar.lib.vt.edu/ejournals/JVTE/v15n1/JVTE7.html 